\title{
Understanding in Literary Translation
}

\author{
Aschen Mikoyan
}

Lomonosov Moscow State University

\begin{abstract}
The article addresses the issue of the importance of a full and adequate understanding of a literary ST on the part of the translator. Understanding is crucial on all levels of the text - lexical meanings and connotations, phraseology, idiomaticity, syntax, stylistic devices and overtones, etc. Apart from these, there are various other aspects of the text - its cultural, historical and literary allusions, various culture-specific terms and other, not necessarily, explicit, elements and features that the translator must fully understand so as to produce an adequate and worthwhile rendering of his/her ST in a different language.
\end{abstract}

Key words: literary translation, comprehension, connotation, equivalence, understanding.

\section{Introduction}

Among the various notions that are associated with translation in general and literary translation in particular there is hardly any that is less questionable than the notion that a truly satisfactory translation depends on an adequate and comprehensive rendering of both form and content, which, in its turn, depends, to a great extent, on the translator's adequate and comprehensive understanding of the source text. It is important to note here that by "an adequate and comprehensive rendering of form" we do not mean what is known as 'formal correspondence', which, as Eugene Nida and Jan de Waard point out, "so frequently does not carry the correct meaning of the source text" (de Waard, Nida 1986:37). It is clear that both these all-important constituents, i.e., the form and the content of a literary work, are themselves complex and multi- 
faceted phenomena. Comprehensive and profound understanding by the translator of all the 'facets' that constitute each of them and make them what they are can be regarded as a conditio sine qua non of a successful translation. At the same time it can be said that it is not a fully realistic condition, and in actual translation practice complete and thorough understanding of the ST in all its entirety and complexity by the translator is not always achieved, which might cause mistranslation of certain elements or even parts of the text. The paper will discuss a number of characteristic examples drawn from a variety of translated literary texts and representing some particular challenges for the translators in terms of their understanding and adequate - or inadequate or erroneous - rendering.

\section{Understanding in Literary Translation}

As had been pointed out above, a truly adequate translation depends on an adequate and comprehensive rendering of both form and content of a literary work. The rendering of form is impossible without paying attention to such aspects of the text as its vocabulary (which in its turn can be represented by a wide range of various types of lexical and phraseological units, idioms, toponyms, anthroponyms, terms, etc.), its syntactic structure (the type and length of sentences, division into paragraphs, FSP, etc.), its various morphological features (e.g., verbal forms, aspect, etc.), and, last but most certainly not least, its stylistic character, constituted by a range of expressive devices on all the above levels plus the level of sounds (assonance, alliteration, paronymic attraction, etc.). Again, it should be pointed out that the above reference to the 'constituents' of form is not intended to promote what was described by John Catford as "rank-bound translation", where ST units of this or that grammatical category are expected to correspond to units of the same grammatical category in the TT. Rank-bound translation establishes "word-toword or morpheme-to-morpheme equivalences, but not equivalences between high-rank units such as the wordgroup, clause or sentence" (Catford 1965:31). Catford contrasted it with "unbound translation", i.e., "normal total translation in which equivalences shift freely up and down the rank scale [ibid]." The latter 
type of translation is, basically, the only of these two that can be applied to translation of works of Literature. Yet each of the 'ranks' constituting a literary text, might play a significant role in it and therefore must be given attention that is due to it in the context of the ST and be treated accordingly.

The content of a literary work, which, needless to say, is inseparable from its form, and depends on the latter just as the latter depends on it, in its turn comprises several levels, or 'layers' of meaning, various implications, connotations, allusions, culture-specific terms (realia), besides direct or indirect 'links' with extralinguistic reality, with the cultural and historical background on which a literary work is created (and in which its story is set), also possibly with the personality and life story of the author. In short, when it comes to understanding a literary work, there is much to understand indeed.

When it comes to translation, understanding, might be said without much exaggeration, to be 'half the battle'. It is hard to overrate the importance of a comprehensive and correct understanding of the source text (ST) - and each and every element of it - on the part of the translator. Understanding is crucial on all the above levels of the text - all the various levels of expression and content, and all other, not necessarily explicit, elements and features of the text. Ideally, the translator must achieve understanding of all the above to be able to produce an adequate and worthwhile rendering of a literary work, which will do full justice to it in a different language.

It seems evident and stands to reason that this kind of understanding is something a native speaker of the language in which a literary work is written is more likely to achieve in full (or, at least, to a larger extent) than someone who was not born with that language and/or within that culture. The same, naturally, is true about the readers of the original of a literary work as against readers of its translation. As Leonid Barkhudarov pointed out in this connection in his work Language and Translation, “...to be able to understand the text that he is translating, the translator must possess a certain store of extralinguistic knowledge", at the same time, he "can by no means expect that this knowledge, essential for the understanding of the text, will be possessed in equal measure by the speakers of L2 and L1. On the contrary, it is perfectly normal and 
common that the scope of extralinguistic knowledge possessed by the L2 speakers does not coincide with the scope of such knowledge possessed by the speakers of L1 - a great deal of what is known and comprehensible to the readers or listeners of the original text turns out to be unknown or incomprehensible to the readers or listeners of its translation (Barkhudarov 1975: 3; Translation - A. M.). So, it might be seen as the translator's task, at least, not to 'cloud' the readers' comprehension even more with his or her inadequate understanding and, ideally, whenever possible, to partially bridge this gap in understanding - though it will never disappear completely.

Yet, the difficulty here lies in a somewhat paradoxical and at the same time indisputably logical fact that literary translation is normally done into one's native language and not from it, i.e., out of $\mathrm{L} 2$ and into L1. The logic behind it is, of course, perfectly sound and obvious: unless the translator's L2 for some reason happens to be at the same or virtually the same level as his L1, his performance in his native tongue is, by definition, better, more natural and correct than his performance in L2. However, the other side of the medal is that the translator's understanding of the foreign text might, at least to some extent and at least in some instances, be inferior to that of educated native speakers reading the same text in their own language. In his Uber die verschiedenen Methoden des Übersetzens, Friedrich Schleiermacher, having enlarged on the difficulty and importance of true and profound understanding of a work of verbal art on all of its many levels in one's own tongue, writes: "Imagine, then, what a high art understanding must be when it has to deal with the products of a distant and foreign language! Whoever has mastered this art of understanding through the most diligent cultivation of a language, the most precise knowledge of the whole historical life of a nation, and the living representation of single works and their authors, he and he alone may wish to unlock that same understanding of the masterpieces of art and scholarship for his own contemporaries and compatriots" (Schleiermacher 1813 in Lefevere 1992:147).

In actual life and in translation practice of today, this high ideal, even if it is sincerely aspired to by conscientious translators, is not often achieved in full 
and in some cases is not achieved at all - sometimes even at much lower levels than those Schleiermacher was writing about, and instances of misinterpretation are far from being rare. Some of such instances are illustrated by the examples considered in the paper and representing fragments of translated texts both in English and Russian. The most obvious level with which to begin seems to be the level of the language, where a considerable proportion of errors and misinterpretations are accounted for by the translator's failure to correctly understand the meaning of a word, a phrase or a sentence.

For the sake of convenience and visual clarity examples are presented in the form of a table, where excerpts from the source texts are juxtaposed with their corresponding translated versions (from published translations). Each instance is commented on in the text that follows each table.

Table 1.

\begin{tabular}{|c|c|c|c|}
\hline & Source text & Translation 1 & Translation 2 \\
\hline & $\begin{array}{l}\text { Н.В. Гоголь, «Мертвые } \\
\text { души». Глава } 1\end{array}$ & $\begin{array}{l}\text { Dead Souls (translated by } \\
\text { D.J. Hogarth, 1915) }\end{array}$ & $\begin{array}{l}\text { Dead Souls (translated } \\
\text { by Christopher } \\
\text { English, 1987) }\end{array}$ \\
\hline 1.1 & $\begin{array}{l}\text { [Наружный фасад } \\
\text { гостиницы отвечал ее } \\
\text { внутренности: она была } \\
\text { очень длинна, в два } \\
\text { этажа;] <...>; верхний был } \\
\text { выкрашен вечною желтою } \\
\text { краскою; внизу были } \\
\underline{\text { лавочки с хомутами, }} \\
\text { веревками и баранками. }\end{array}$ & $\begin{array}{l}1.1 .1<. .>\text { As for the upper } \\
\text { half of the building, it } \\
\text { was, of course, painted } \\
\text { the usual tint of unfading } \\
\text { yellow. Within, on the } \\
\text { ground floor, there stood } \\
\text { a number of benches } \\
\text { heaped with horse- } \\
\text { collars, rope, and } \\
\text { sheepskins; }\end{array}$ & $\begin{array}{l}1.1 .2<\ldots>\text { the upper } \\
\text { was painted the } \\
\text { inevitable yellow; on } \\
\text { the ground floor were } \\
\text { little shops selling } \\
\text { harness, ropes and } \\
\text { bread rolls. }\end{array}$ \\
\hline 1.2 . & $\begin{array}{l}\text { В угольной из этих } \\
\text { лавочек, } \\
\text { или, лучше, в окне, } \\
\text { помещался сбитенщик с } \\
\text { самоваром из красной } \\
\text { меди и дицом так же } \\
\text { красным, как самовар, так } \\
\text { что издали можно бы }\end{array}$ & $\begin{array}{l}1.2 .1 \\
\text {... while the window-seat } \\
\text { accommodated a } \\
\text { sbitentshik }^{*} \text {, cheek by } \\
\text { jowl with a samovar } \\
\text { the latter so closely } \\
\text { resembling the former in } \\
\text { appearance that, but for } \\
\text { the fact of the samovar }\end{array}$ & $\begin{array}{l}1.2 .2 \\
\text { In the corner shop, or, } \\
\text { to be more precise, at } \\
\text { the window of it, a } \\
\text { honey-tea vendor } \\
\text { stood beside his } \\
\text { copper samovar. His } \\
\underline{\text { face was just as }} \\
\text { coppery as his }\end{array}$ \\
\hline
\end{tabular}




\begin{tabular}{|l|l|l|l|}
\hline $\begin{array}{l}\text { подумать, что на окне } \\
\text { стояло два самовара, если } \\
\text { б один самовар не был с }\end{array}$ & $\begin{array}{l}\text { possessing a pitch-black } \\
\text { lip, the samovar and the } \\
\text { sbitentshik might have } \\
\text { been two of a pair. 6 }\end{array}$ & $\begin{array}{l}\text { samovar, so that from } \\
\text { afar one might have } \\
\text { thought that there } \\
\text { were two samovars } \\
\text { бородою. как смоль, }\end{array}$ & $\begin{array}{l}\text { бtanding in the } \\
\text { window, had not one } \\
\text { of them sported a }\end{array}$ \\
& $\begin{array}{l}\text { *An urn for brewing } \\
\text { honey tea. } \\
\text { **An urn for brewing } \\
\text { ordinary tea. }\end{array}$ & \begin{tabular}{l} 
pitch-black beard. \\
\hline
\end{tabular} \\
\end{tabular}

Although the above examples come from a complicated and, languagewise, a very rich text, which would not have lent itself easily to translation, some of the mistakes made by one of the two translators quoted here ${ }^{1}$, still seem a bit 'extreme'. As a matter of fact, D.J. Hogarth's translation was rather severely criticized for its numerous errors and the excessive 'freedom' with which he treated the text. Thus, in the words of Semion Rapoport quoted by Rachel May in her book The Translator and the Text, "Mr Hogarth has a very poor knowledge of Russian but a rich fancy <...> and decorates Gogol with such ornaments of style as to make him unrecognizable" (Rapoport 1928:505, in May 1994:35). At the same time, it might be said in Hogarth's defence, that he was one of the earliest translators of Gogol's poem, and he was working on it at the time when reliable and comprehensive Russian-English dictionaries must have been few and far between. This can to some extent explain certain instances of mistranslation (although certainly not the 'flights of his fancy', mentioned by Rapoport). Yet, what the above examples demonstrate is not so much the translator's "poor knowledge of Russian" (although this too is rather evident) as his failure to understand the meaning of certain words, phrases and descriptions in the given context. It is this failure to understand that led to the above mistranslations. None of the mistranslated words or parts of sentences in these short excerpts can be supposed to have been 'difficult' for or unknown to the translator. He obviously knew the word “вечный” in “...выкрашен вечною желтою краскою" (ех.1.1) and he must have thought he understood its meaning in the context, translating it as "unfading (yellow)," while in fact what 
Gogol meant was not "unfading" but "invariably seen on the walls of provincial inns" (that is to say, the word refers not to the 'durability' but to the 'predictability' of colour). Even though Hogarth adds the words "the usual tint of...", it still seems that he was not certain which of the meanings of «вечный» was meant here and decided on a kind of compromise - although, giving him the benefit of the doubt, as it were, we can also suppose that he deliberately played on the polysemy of the word “вечный." Christopher English, whose very competent version, ${ }^{2}$ is represented here side by side with Hogarth's, used the word "inevitable," thus supplying an appropriate translation equivalent that conveys the true meaning of its Russian counterpart.

The two other instances of misunderstanding (and complete misunderstanding at that) to be noted in D.J. Hogarth's translation of the same sentence (ex. 1.1) are "benches" for “лавочки" (instead of "little shops") and "sheepskins" for “баранки" (instead of "bread rolls", "cracknels”, etc.). Here indeed it was probably Hogarth's insufficient knowledge of Russian that led to his confusing “лавочка" (a small shop), i.e., a derivative of “лавка" (a shop), with its homonym meaning "a small bench". It is more difficult to explain how “баранки" ended up as "sheepskins", since "баранки" have no connection with sheep whatsoever; they are rings made of yeast dough, which, like Polish bagels or Italian ciambelle all'acqua, are prepared by being dipped into boiling water before going into the oven. It can be supposed that the translator, misled by the similarity between the words "баранки" and "баран" (a ram) and puzzled by the presence of "rams" on "benches", rendered "баранки" as "sheepskins" for lack of a better idea.

Example 1.2 illustrates another instance of flagrant misunderstanding on Hogarth's part. First of all, he misunderstood the word "сбитенщик" ("hot-tea vendor" in Ch. English's descriptive translation), which he transcribed as "sbitenshchik" and supplied with a footnote reading "An urn for brewing honey tea" (as against "samovar", which is explained by him in another footnote as "An urn for brewing ordinary tea"). This led him to the misunderstanding of the final clause in the sentence, in which Gogol says that if one of the "samovars" (i.e. the vendor himself, of course) had not possessed a pitch-black 
beard, they could have been taken for a pair of samovars from a distance (“...издали можно бы подумать, что на окне стояло два самовара, если б один самовар не был с черною, как смоль, бородою.”). D.J. Hogarth was evidently confused by the fact that the man is humourously referred to here as "one of the samovars" - a kind of 'follow-up' to his earlier words to the effect that the "honey-tea vendor's" face was as red as his copper samovar. As a result, he understood this clause literally, hence his somewhat bizarre description of a samovar "possessing a pitch-black lip." In addition, Hogarth placed both the sbitenshchik and his samovar on a window-seat, which is not what the words "в окне" (lit. "in the window") suggest.

Table 2.

\begin{tabular}{|c|c|c|c|}
\hline & Source text & Translation 1 & Translation 2 \\
\hline & $\begin{array}{l}\text { Dorothy Sayers, The } \\
\text { Nine Tailors }\end{array}$ & $\begin{array}{l}\text { «Девять ударов за } \\
\text { упокой», translated by } \\
\text { Maria Vorsanova (Мария } \\
\text { Ворсанова), } 1998\end{array}$ & $\begin{array}{l}\text { «Почерк убийцы» } \\
\text { («Девять портных»), } \\
\text { translated by A. Yashina } \\
\text { (A.B. Яшина), } 2008\end{array}$ \\
\hline 2.1 & $\begin{array}{l}\text { “Oh, I'm sorry, sir. I } \\
\text { thought you were some } \\
\text { of the men. Your car } \\
\text { broke down? That's } \\
\text { bad. Come in. I'm } \\
\text { afraid we are all in a } \\
\text { muddle... }\end{array}$ & 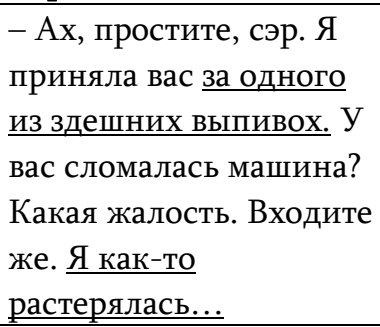 & $\begin{array}{l}\text { — О, простите, сэр! Я } \\
\text { подумала, что вы один из } \\
\text { тех мужчин. У вас } \\
\text { сломалась машина? Это } \\
\text { плохо. Проходите. } \\
\text { Только у нас тут } \\
\text { ужасный беспорядок. }\end{array}$ \\
\hline 2.2 & $\begin{array}{l}\text { "Oh, dear," said the } \\
\text { clergyman. "Such a } \\
\text { terrible day, too! Can I } \\
\text { be of any assistance?" }\end{array}$ & $\begin{array}{l}\text { - Вот те на! - огорчился } \\
\text { священник. - В такую- } \\
\text { то погоду! Могу я вам } \\
\text { чем-нибудь помочь? }\end{array}$ & $\begin{array}{l}\text { — О, Боже мой! Какая } \\
\text { неприятность! — } \\
\text { воскликнул падре. — Да } \\
\text { еще и в такую ужасную } \\
\text { погоду! Я могу вам как- } \\
\text { нибудь помочь? }\end{array}$ \\
\hline 2.3 & $\begin{array}{l}\text { "But couldn't we get } \\
\text { rooms at an inn or } \\
\text { something? I'm really } \\
\text { ashamed..." } \\
\text { "My dear sir, praydon't } \\
\text { think twice about it. }\end{array}$ & $\begin{array}{l}\text { - И все же, нельзя ли } \\
\text { снять комнаты в какой- } \\
\text { нибудь гостинице или } \\
\text { где-нибудь еще? Мне, } \\
\text { право, неловко... } \\
\text { - Дорогой сэр, умоляю, } \\
\text { не стоит больше об } \\
\text { этом. }\end{array}$ & $\begin{array}{l}\text { - Может, все же будет } \\
\text { удобнее, если мы } \\
\text { снимем номер в } \\
\text { гостинице? Мне } \\
\text { действительно очень } \\
\text { неудобно... } \\
\text { — Прошу вас, } \underline{\text { не }} \\
\text { меняйте своего решения. }\end{array}$ \\
\hline
\end{tabular}




\begin{tabular}{|c|c|c|c|}
\hline 2.4 & $\begin{array}{l}<\ldots>\text { Here we are. } \\
\text { I always blow my horn } \\
\text { here; the wall and the } \\
\text { trees make it so very } \\
\text { dangerous. } \\
<\ldots>\text { Here is the } \\
\text { Rectory }- \text { just opposite } \\
\text { the church. I always } \\
\text { blow my horn for fear } \\
\text { anybody should be } \\
\text { about. } \\
<\ldots>\text { I always blow my } \\
\text { horn at the door, so as } \\
\text { to tell my wife I am } \\
\text { back. }\end{array}$ & $\begin{array}{l}\text { <..> Вот и жилище } \\
\text { пастора - сразу за } \\
\text { церковью. } \underline{\text { я всегда }} \\
\text { сигналю, въезжая в } \\
\text { ворота. На случай, если } \\
\text { кто-нибудь бродит по } \\
\text { двору. <...> У дверей я } \\
\text { тоже всегда сигналю, } \\
\text { чтобы жена знала - я } \\
\text { приехал. }\end{array}$ & 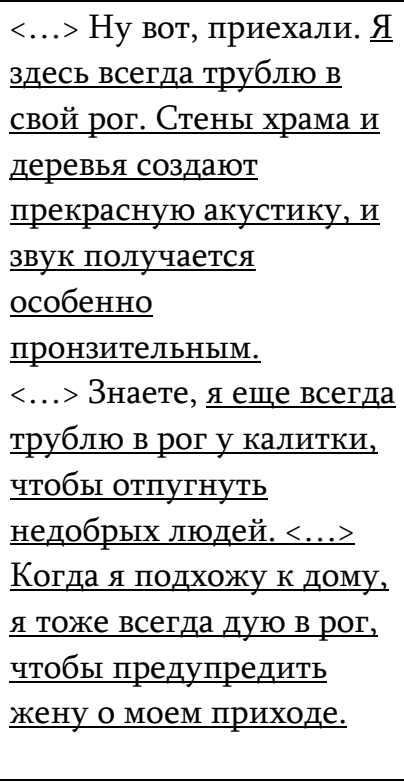 \\
\hline 2.5 & $\begin{array}{l}\text { "Will you come up now } \\
\text { and see your room? } \\
\text { You will like a wash } \\
\text { and brush-up at any } \\
\text { rate. } \\
\text { (Mrs Venables to Lord } \\
\text { Wimsey) }\end{array}$ & $\begin{array}{l}\text { Не хотите подняться } \\
\text { наверх и посмотреть } \\
\text { свою комнату? Вы } \\
\text { сможете умыться и } \\
\text { освежиться. }\end{array}$ & $\begin{array}{l}\text { - Может быть, сейчас } \\
\text { поднимемся на второй } \\
\text { этаж, и я покажу вам } \\
\text { вашу комнату? Я думаю, } \\
\text { в любом случае, вы с } \\
\text { удовольствием примете } \\
\text { душ и освежитесь. }\end{array}$ \\
\hline 2.6 & $\begin{array}{l}\text { "My library is, I fear, } \\
\text { limited, but I have an } \\
\text { edition of the Gospel of } \\
\text { Nicodemus that may } \\
\text { interest you." } \\
\text { (Mr Venables to Lord } \\
\text { Wimsey) }\end{array}$ & $\begin{array}{l}\text { - Моя библиотека, увы, } \\
\text { не слишком обширна, } \\
\text { но в ней есть издание } \\
\text { «Евангелия от } \\
\text { Никодима», которое } \\
\text { может вас } \\
\text { заинтересовать. }\end{array}$ & $\begin{array}{l}\text { - Конечно, моя } \\
\text { библиотека, к } \\
\text { сожалению, не } \\
\text { отличается особым } \\
\text { размахом, но у меня есть } \\
\text { одно преинтересное } \\
\text { издание, которое может } \\
\text { вас заинтересовать - } \\
\text { «Проповеди } \\
\text { Никодемуса» }\end{array}$ \\
\hline
\end{tabular}

The above examples come from Dorothy Sayers' detective novel The Nine Tailors and its two translations into Russian, published in 1998 and 2008 respectively. The very first challenge presented by this novel to the translator is its title, which, as it is usually the case, should not be translated in a hurry, that 
is to say, before the book is read, for a literal translation of it (which actually features as an alternative title of the 2008 Russian version) would be definitely wrong. It has nothing to do with any tailors, and means exactly what M. Vorsanova chose as the title for her version: nine strokes of the funeral bell, which, in accordance with an old English village tradition, were rung at a male villager's death (while six strokes proclaimed a woman's death). In the fictional village of Fenchurch St Paul, where Dorothy Sayers set her novel, the lowestpitched bell of St Paul's Church (or the tenor bell as it is known in the English bell-ringing tradition) is named Tailor Paul, with all the other seven bells having their distinctive names too. And since it is Tailor Paul that traditionally tolls for the deceased, its funeral strokes are referred to by the villagers as 'tailors', hence The Nine Tailors.

Unlike the above examples from Dead Souls, in this sequence of examples it is not the earlier but the later of the two translated versions that is less successful and contains a much larger amount of errors of various kinds, including those that are accounted for by the translator's failure to understand either the text or the context, or both. Thus, in example 2.1, it is the definite article before the noun 'men' that was misinterpreted by A. Yashina, who, without any regard for the context of the episode (set outside a village pub prior to its opening hours), rendered it with the help of the Russian demonstrative pronoun "тех" - the accusative of “те" ("those"). For the publican's wife ${ }^{3}$ to say that she took Lord Wimsey (and his companion) for "some of those men" there ought to be some men about, whom both she and he could see or at least of whose existence both she and Lord Wimsey would be aware. But what she says is "I thought you were some of the men". The difference appears to be slight yet it is significant, for what the woman implies is, perhaps, a guessing matter to Lord Wimsey yet something very definite to her - the men of the village who frequent her pub. Of the two translators it was only M. Vorsanova who understood that implication, and, although her rendering is longer and more explicit than the original (lit. "one of the local boozers"), it gives full justice to the contextual meaning of "the" in the sentence. The only fault of Vorsanova's version is that she substituted "оnе" (“один”) for "some," thus disregarding the 
fact that Lord Wimsey was not alone but accompanied by his valet. In rendering the last sentence in this sequence (ex. 2.1), "I'm afraid we are all in a muddle..." neither of the translators demonstrates due regard for the context. What the publican's wife refers to here is the state of worry and concern she is in because of her husband's suddenly falling victim to the epidemic of influenza raging in the village. Neither of the translated versions conveys this meaning, and, while Vorsanova's rendering (“Я как-то растерялась...”) suggests that the woman has got confused at that very moment and can't collect her wits because of the strangers' arrival (which is not the case), in Yashina's translation (“Только у нас тут ужасный беспорядок") Mrs Tebbutt seems to be apologetically warning the visitors about the untidiness of the house.

Example 2.2 demonstrates A. Yashina's neglect of the context of a higher level. In rendering "clergyman" аs "падре" ("padre") - here and in many other instances throughout the book, the translator shows lack of understanding of (or deliberate disregard for) the extralinguistic reality in relation to the religious situation in England and its reflection in Sayers' novel. Mr Venables is an Anglican clergyman; he introduces himself to Lord Wimsey with the words "My name, by the way, is Venables - <..> I am the rector of the parish". It should be clear from this introduction and from the context of the book as a whole that Mr Venables is not a Catholic priest. In the original text of the novel "padre" is indeed used several (fifteen) times - but only as a form of direct address and only by Lord Peter, as a rather informal and somewhat humourous (Spanish) version of 'Father'. The latter, alongside 'Reverend', 'Rector' and $\mathrm{Mr}$ So-and-So, could be used to address a Church-of-England clergyman. In Russian, however, the word "падре" is associated only with Catholic priests, which Mr Venables is definitely not. Therefore it should not have been used by the translator in the author's narration (in the original he is referred to, alternatively, as 'the clergyman', 'Mr Venables and 'the Rector'). The other translator quite sensibly went for the neutral words “священник” (clergyman) and "пастор" (pastor).

Examples 2.3 and 2.4 demonstrate flagrant misunderstanding of the ST utterances by A. Yashina. In 2.3 the rector's words "My dear sir, pray don't 
think twice about it," with which he urges Lord Wimsey to accept his offer of hospitality without hesitation, are translated with the Russian sentence that means, literally, "Do not change your decision" (it seems that the translator confused "thinking twice" with "having second thoughts"). Yashina's translation of the sentences in 2.4 creates an amusing, if not bizarre picture of Mr Venables the Rector literally blowing into a hunting or a Viking horn on the way home, instead of using his car horn to warn off pedestrians. The noun she used in Russian, unlike the English "horn", has no association with cars whatever and means either "a horn of a bull, etc." or "a simple instrument made from the horn of an animal" (Macmillan English Dictionary). The verb used with it is the verb describing the physical action of blowing air into such a horn, so as to extract a sound. The 1998 translation, by contrast, features the verb "сигналить" (to signal), which is just the verb used in Russian for blowing a car horn. As for the reason why the rector blows his horn at certain points of the road, A. Yashina had a problem with understanding it as well, the result of it being a translation that can only mislead the reader. First we read in her translated version that Mr Venables explains his 'horn-blowing exercise' by “the fine acoustics created by the walls of the church and the trees, which makes the sound [of the horn] particularly piercing" and then, as he and Wimsey reach the Rectory gate, that his horn-blowing is intended "to scare off bad people". In actual fact, as the English text half explicitly, half implicitly lets us know, the rector blows his car horn in places where he can't see the road far ahead so as to warn off possible pedestrians and thus to avoid an accident.

The final two examples in Table 2 demonstrate the importance of relevant background knowledge for an adequate translation of the text. In example 2.5, Mrs Venables, the rector's wife, is offering to take her guest to his room, adding: "You will like a wash and brush-up at any rate." In the 1998 translation it is appropriately and noncommittally rendered as "Вы сможете умыться и освежиться, " meaning, literally, "You'll be able to wash and freshen up", while the other translator's faulty understanding results in Mrs Venables supposing that Lord Wimsey "would enjoy taking a shower." Anyone acquainted (through books or other sources) with what life in an English village was like at the time 
when the novel is set, i.e., the early 1930s, would know that showers were practically non-existent. In those days most English rural homes were equipped only with bathtubs, and with separate taps for hot and cold water too, and certainly not showers. For many old houses it is still true today. So Mrs Venables' remark about Lord Wimsey's “taking a shower” in the 2008 version seems flagrantly inappropriate and comes from the translator's failure to understand the broad context of the book she was translating.

And, finally, the last example in Table 2, where the 2008 translation features a double mistake in the title quoted by Mr Venables. The mistakes are so obvious that they hardly deserve any comment - "the Gospel" is mistranslated as "Sermons", and, instead of the traditional Russian version of Nicodemus's name ("Nikodim" - appropriately used in the 1998 translation, together with the correct word for the Gospel), Yashina simply transcribes the English version. It is not the question of understanding here, for there is nothing much to understand in the title. It is rather the question of deficient background knowledge and negligence on the translator's part. But there is a point in the sentence at large, where adequate understanding was important and where A.Yashina was wide of the mark again. "I have an edition of the Gospel of Nicodemus that may interest you," says Mr Venables to Lord Wimsey. "An edition" suggests that there have been a number of editions, and "that", unpreceded by a comma, introduces a limiting relative clause signifying that it's this particular edition that, in the rector's opinion, might interest his guest. While M. Vorsanova understood and translated this sentence correctly, A.Yashina, failing to comprehend the grammatical indicators of meaning, produced a rendering with misplaced accents. In a literal translation back into English it reads as follows: "...I have one extremely interesting edition [=a book] that may interest you - The Sermons of Nikodemus." What we deal with here, therefore, is lack of adequate understanding on the level of grammar, which is, in fact, quite an important level deserving the translator's full attention.

Examples that follow are intended to illustrate the importance of adequate understanding of the stylistic and socio-cultural features of a literary text, 
which are sometimes not immediately apparent and do not always lie on the surface, as it were. These examples come from The Master and Margarita by Bulgakov and three English translations of the novel.

Table 3.

\begin{tabular}{|c|c|c|c|}
\hline & $\begin{array}{l}\text { The Master and Margarita, } \\
\text { translated by Mirra } \\
\text { Ginsburg (1967) }\end{array}$ & $\begin{array}{l}\text { The Master and } \\
\text { Margarita, translated by } \\
\text { Michael Glenny (1967) }\end{array}$ & $\begin{array}{l}\text { The Master and } \\
\text { Margarita, transl. by } \\
\text { Richard Pevear \& } \\
\text { Larissa Volokhonsky } \\
\text { (1997) }\end{array}$ \\
\hline 3.1 & \multicolumn{3}{|c|}{$\begin{array}{l}\text { Однажды весною, в час небывало жаркого заката, в Москве, на Патриарших } \\
\text { прудах, появились два гражданина. }\end{array}$} \\
\hline & $\begin{array}{l}\text { At the hour of sunset, on a } \\
\text { hot spring day, two } \\
\text { citizens appeared in the } \\
\text { Patriarchs' Ponds Park. }\end{array}$ & $\begin{array}{l}\text { At the sunset hour of one } \\
\text { warm spring day two } \\
\text { men were to be seen at } \\
\text { Patriarch's Ponds. }\end{array}$ & $\begin{array}{l}\text { At the hour of the hot } \\
\text { spring sunset two } \\
\text { citizens appeared at the } \\
\text { Patriarch's Ponds. }\end{array}$ \\
\hline 3.2 & \multicolumn{3}{|c|}{ Речь эта, как впоследствии узнали, шла об Иисусе Христе. } \\
\hline & $\begin{array}{l}\text { The conversation, as we } \\
\text { learned subsequently, was } \\
\text { about Jesus Christ. }\end{array}$ & $\begin{array}{l}\text { They had been talking, it } \\
\text { seemed, about Jesus } \\
\text { Christ. }\end{array}$ & $\begin{array}{l}\text { This conversation, as } \\
\text { was learned afterwards, } \\
\text { was about Jesus Christ. }\end{array}$ \\
\hline 3.3 & \multicolumn{3}{|c|}{$\begin{array}{l}\text { Впоследствии, когда, откровенно говоря, было уже поздно, разные } \\
\text { учреждения представили свои сводки с описанием этого человека. }\end{array}$} \\
\hline & $\begin{array}{l}\text { Afterwards, when - } \\
\text { frankly speaking - it was } \\
\text { already too late, various } \\
\text { official institutions filed } \\
\text { reports describing this } \\
\text { man. }\end{array}$ & $\begin{array}{l}\text { Afterwards, when it was } \\
\text { frankly too late, various } \\
\text { persons presented their } \\
\text { data and issued } \\
\text { descriptions of this man. }\end{array}$ & $\begin{array}{l}\text { Afterwards, when, } \\
\text { frankly speaking, it was } \\
\text { already too late, various } \\
\text { institutions presented } \\
\text { reports describing this } \\
\text { man. }\end{array}$ \\
\hline 3.4 & \multicolumn{3}{|c|}{$\begin{array}{l}\text { - Взять бы этого Канта, да за такие доказательства года на три на Соловки! - } \\
\text { совершенно неожиданно бухнул Иван Николаевич. } \\
\text { - Иван! - сконфузившись, шепнул Берлиоз. }\end{array}$} \\
\hline & $\begin{array}{l}\text { "This Kant ought to be } \\
\text { sent to Solovki for three } \\
\text { years for such arguments!" } \\
\text { Ivan Nikolayevich burst } \\
\text { out suddenly. "Ivan!" } \\
\text { Berlioz whispered in } \\
\text { embarrassment. }\end{array}$ & $\begin{array}{l}\text { "Kant ought to have been } \\
\text { arrested and given three } \\
\text { years in Solovki asylum } \\
\text { for that 'proof' of his!" } \\
\text { Ivan Nikolayevich burst } \\
\text { out completely } \\
\text { unexpectedly. } \\
\text { "Ivan!" whispered Berlioz, }\end{array}$ & $\begin{array}{l}\text { "They ought to take } \\
\text { this Kant and give him } \\
\text { a three-year stretch in } \\
\text { Solovki for such } \\
\text { proofs!" Ivan } \\
\text { Nikolaevich plumped } \\
\text { quite unexpectedly. } \\
\text { "Ivan!" Berlioz }\end{array}$ \\
\hline
\end{tabular}




\begin{tabular}{|c|c|c|c|}
\hline & & $\mathrm{mb}$ & $\begin{array}{l}\text { whispered, } \\
\text { embarrassed. }\end{array}$ \\
\hline \multirow[t]{2}{*}{3.5} & \multicolumn{3}{|c|}{$\begin{array}{l}\text { - Алмаз вы наш небесный, драгоценнейший господин директор, - } \\
\text { дребезжащим голосом ответил помощник мага, - наша аппаратура всегда при } \\
\text { нас. (Koroviev to Rimsky) }\end{array}$} \\
\hline & $\begin{array}{l}\text { "Our diamond from } \\
\text { heaven, our most precious } \\
\text { Mister Manager," the } \\
\text { assistant quavered, "our } \\
\text { paraphernalia are always } \\
\text { with us." }\end{array}$ & $\begin{array}{l}\text { "Why, bless you, my dear } \\
\text { sir," replied the } \\
\text { magician's assistant, "we } \\
\text { have all the equipment } \\
\text { we need with us now, } \\
\text { look!" }\end{array}$ & $\begin{array}{l}\text { "Our heavenly } \\
\text { diamond, most precious } \\
\text { mister director," the } \\
\text { magician's assistant } \\
\text { replied in a rattling } \\
\text { voice, "the } \\
\text { paraphernalia is always } \\
\text { with us. Here it is!" }\end{array}$ \\
\hline 3.6 & \multicolumn{3}{|c|}{$\begin{array}{l}\text { К необыкновенному исчезновению Лиходеева присоединилось совершенно } \\
\text { непредвиденное исчезновение Варенухи. Римскому было известно, куда он } \\
\text { ушел, но он ушел и... не пришел обратно. Римский пожимал плечами и } \\
\text { шептал сам себе: } \\
\quad \text { - Но за что?! }\end{array}$} \\
\hline & $\begin{array}{l}<\ldots>\text { Rimsky knew where } \\
\text { he had gone, but he left ... } \\
\text { and he had not returned! } \\
\text { Rimsky shrugged his } \\
\text { shoulders and whispered } \\
\text { to himself: } \\
\text { "But why?" }\end{array}$ & $\begin{array}{l}\text { Rimsky knew where } \\
\text { Varenukha had been } \\
\text { going, but the man had } \\
\text { simply gone and never } \\
\text { came back. He shrugged } \\
\text { his shoulders and } \\
\text { muttered to himself: "But } \\
\text { why?" }\end{array}$ & $\begin{array}{l}\text { Rimsky knew where he } \\
\text { had gone, but he had } \\
\text { gone and ... not come } \\
\text { back! Rimsky shrugged } \\
\text { his shoulders and } \\
\text { whispered to himself: } \\
\text { "But what for?" }\end{array}$ \\
\hline
\end{tabular}

What is of interest to us here is how the three translators dealt with the socio-cultural-ideological elements of the text reflecting the political and ideological situation in Russia at the time when Bulgakov was writing his great novel (1929-1940) and the time and place in which its action is set, i.e., Moscow in the 1920s. Many of these elements, affecting both its content and, possibly, also its form, might perhaps be perceived by the Western reader as 'incomprehensible', 'alien' or simply 'unusual' or 'unknown'. While dealing with such features, the translator ideally must not only be conscious of their existence and their meaning in the given text, but also understand as fully as possible their meaning and significance within the framework of the source 
culture as a whole. Without this understanding, his or her translation, for all its possible merits, will fall short of re-creating the atmosphere permeating the original work, and the target readers will be deprived of an important part of its intrinsic value - not only as a work of verbal art but also as a product of a certain culture, a culture different from their own.

And now for the examples. The first one in this group (ex. 3.1) is the instantly recognizable opening sentence of the novel, introducing two characters of the book, and the difference between the approaches chosen by the translators becomes apparent right away. To be more precise, it is one of the three versions that stands out against the background of the other two. The word used by Bulgakov here is the plural form of "гражданин”, of which "citizen" is the direct English equivalent. To the Russian readers this word is an indication of at least two things: a) the author's somewhat ironic or humorous attitude to these two characters, and b) the post-1917 setting of the novel. The pre-1917 forms of polite indirect reference to people, such as "господин" (gentleman) or "дама" (lady) after the 1917 revolution were ousted from usage by the words “гражданин” (citizen) and “товарищ” (comrade). Michael Glenny does not seem to have understood or appreciated the significance of the word chosen by the author and replaced it with a perfectly neutral word "men," thus 'levelling out' the sentence, as it were, and depriving it of its socio-cultural character and mildly ironic touch.

In sentence 3.2, "Речь эта, как впоследствии узнали, шла об Иисусе Христе," only the 1997 translation treats the underscored sequence of words in a way that preserves the somewhat sinister connotation achieved by the impersonal form, “...as was learned afterwards," suggesting an official investigation that must have followed the death of Berlioz. Both M. Ginsburg's version ("as we learned subsequently...") and that of M. Glenny ("They had been talking, it seemed, about Jesus Christ") fail to convey this connotation completely.

Example 3.3 is similar to 3.2 in its allusion to the authorities investigating the Woland-related events: “разные учреждения", which both Ginsburg and the Pevear \& Volokhonsky team translated with appropriate literalness as 
"various institutions" (following the author also in the choice of verbs describing their actions - "filed/presented reports"). M. Glenny's version, however, stands out again with its failure to render an important detail - and replaces it with details of his own invention: “...various persons presented their data and issued descriptions..." The same can be said of the next example (3.4), where Glenny's rendering is wide of the mark again. Failing to appreciate the significance of a reference to Solovki (even in the humourous context in which Bulgakov places it in this sentence) - "the mother of the Gulag" in A. Solzhenitsyn's words - and makes Ivan Bezdomny (Ivan Homeless) refer to it as "the Solovki asylum," thus misleading at least some of the target readers into believing that Solovki was nothing more sinister than a lunatic asylum. In addition, Glenny does away with the demonstrative pronoun "этот" (this), and, besides, uses a perfect infinitive form instead of a simple infinitive thus changing the implication and effectively destroying the humour of the original remark (the demonstrative pronoun and the simple infinitive after the modal verb make it clear that Ivan does not know who Kant is and believes he is still alive and, at least in theory, can still be subjected to his proposed treatment).

Example 3.5 concerns stylistic features (namely those used to create a speech portrayal of a character) more than anything else, and here, too, we find that one of the translators, predictably, Michael Glenny again, either did not understand the role of these features in the text or chose to ignore them, which in itself shows somewhat deficient understanding - not only of the value of such elements in the text but also of his duty as translator. The words "why, bless you, my dear sir," with which he 'mistranslates' Koroviev's flowery mockpolite address, could have come from any English novel, and there is nothing in them that would help to identify the speaker as a particular character of a particular book.

And, finally, the last excerpt to be considered in the article - example 3.6, which represents more subtle issues, directly related to the atmosphere of suspicion, fear and implicit tension that characterized the life of Soviet people under Stalin from the 1920s onwards. Bulgakov does not make any explicit references to it or to Stalin's terror as such; all his references are oblique, yet 
perfectly obvious to the Russian readers of The Master and Margarita, especially those of the older generations. In the episode preceding the one example 3.6 represents, the only such reference is "там" - the Russian word for "there", very probably implying the secret police - the dreaded NKVD. Rimsky, the financial director of the Variety Theatre, following the mysterious disappearance of the Director (in whose name a number of bizarre telegrams have arrived), instructs the administrator, Varenukha, with all the telegrams in his briefcase, to go... there. This pronoun is the only 'identification' of Varenukha's destination we find in the text: "Go right now, Ivan Savelyevich, take it there personally. Let them sort it out [In the original this last sentence is impersonal]." (Pevear \& Volokhonsky), says Rimsky to Varenukha, who does not ask, where exactly he is being sent and who will sort it out, because he knows - so he leaves.

When, after many hours he does not return to the Theatre or phone Rimsky, the latter decides that they have got hold of Varenukha, in other words, he has been arrested. Rimsky does not question this assumption, but he can't understand for what reason or for what offence they have arrested him. And this is the question that torments him that night as he sits in his office in the VarietyTheatre. The question "But why?" in Ginsburg's and Glenny's versions can be easily taken to refer to the words in the author's speech: "he left... and he had not returned!" So, the readers of these translations are likely to assume that Rimsky is asking himself why Varenukha did not return to the Theatre - nothing especially sinister in that.

Not so in Bulgakov's own text, where the Russian "Но за что?!" (lit. "But for what?!") can imply only one question, that is, 'For what was he arrested?' We find this wording in only one translation of the three, i.e., in that by Pevear and Volokhonsky. It might in fact be the presence of a native Russian speaker (Larissa Volkhonsky) in the family team that ensures a fuller and subtler understanding and a more precise rendering of such textual nuances as this one. It is all the more surprising therefore that they, along with both other translators, overlooked not only the double punctuation mark after " Но за что?!" (which, admittedly, would have perhaps looked odd in English), revealing Rimsky's agitation and worry, but also another clear indication of his 
emotional state in Bulgakov's text. It is not a lexical but a grammatical indication, namely, the use of the imperfective aspect of the verbs meaning "shrug [one's shoulders]" and "whisper" respectively, which suggests repeated, or continuous and not one-off, actions. That is to say, Rimsky was [continuously] shrugging his shoulders and he was [continuously] whispering to himself one and the same agonizing question. This suggests a much more significant nervous strain and emotional involvement than, as all three translations have it, a 'single' shrugging of the shoulders and a 'single' whispering of the question.

\section{Conclusion}

Although each of the above examples, taken as an isolated case, might be seen as a rather minor or insignificant fault of the translations in question, such instances demonstrate that the understanding vs. non-understanding or misunderstanding of a literary source text in all its complexity and entirety on the part of the translator are extremely important factors. They affect the overall quality of translation and the degree of adequacy and fullness with which the source text, and all its constituent elements and characteristics - its style, its artistic merit, its storyline, and its socio-cultural-ideological-historical content, to say nothing of its purely linguistic features - are represented in the target text. It is obvious that the likelihood of errors and misinterpretations caused by the failure to understand - or to understand correctly - certain points in the text, both explicit and implicit, is inversely related to the translator's qualification and professionalism, to the translator's command of L2, general background knowledge, his or her cultural and language awareness, and so on. Language awareness of a literary translator implies, among other things, a kind of 'vigilance' - a habit of not easily taking all apparently simple and straightforward elements of the text 'at face value', as it were, and of being alert to the possibility of hidden meanings, implicit connotations, disguised allusions and other important elements and features of the text, which, together with its other, more explicit features and its overall content, constitute the uniqueness 
of a work of verbal art and its intrinsic artistic value as a phenomenon of a given national culture.

\section{Notes:}

1. Encyclopedia of Literary Translation into English (see References) mentions thirteen English translations of Gogol's poem altogether (p. 549).

2. Thomas P. Hodge, author of the article on English translations of Gogol's works in the Encyclopedia of Literary Translation into English, writes that Christopher English'e translation of Dead Souls "takes its place at the top of the list [of translations of the poem - A.M.]. He praises English's thoroughness and his style as a translator: "Instead of avoiding the numerous difficulties of translating Mertvye Dushi, English addresses them directly and cogently in a translator's foreword and numerous explanatory endnotes. There are also scores of enormously helpful endnotes elucidating the key aspects of the 19th-century Russian culture, politics and history. The style of the translation itself is an admirable blend of appropriately arcane and convoluted British English in a humourously playful register" (see Encyclopedia 2000:550).

3. She says it to apologize to Lord Wimsey for having first denied entrance to the pub to him and his servant (neither of whom she has ever seen before).

\section{References:}

1. Barhudarov, L.S. (1975) Jazyk i perevod. Moskva: Mezhdunarodnye otnoshenija.

2. Catford, J.C. (1965) A Linguistic Theory of Translation: an Essay on Applied Linguistics. London: OUP.

3. (2000) Encyclopedia of Literary Translation into English. Chicago, Illinois, USA: Fitzroy Dearborn Publishers.

4. May, R. (1994) The Translator in the Text: on reading Russian Literature in English. USA: Northwestern University Press.

5. Nida, E.A.; Waard, J. de. (1986) From One Language to Another. New York: Thomas Nelson Publishers. 
6. Rapoport, S. (1928) Translation and Translators. // Contemporary Review, 133.

7. Schleiermacher F. (1992) Uber die verschiedenen Methoden des Übersetzens. // Translation. History. Culture. London. / Ed. by A. Lefevere. New York: Routledge.

8. The Literary Texts and Their Translations. Available at <https://culturesconnection.com/different-types-of-translation-services/> [Accessed March 2019].

\section{Sources of Data:}

1. Bulgakov, M. (1980) Master i Margarita. M.: Hudozhestvennaja literatura.

2. Bulgakov, M. (1985) The Master and Margarita. / Tr. by M. Glenny. New York: New American Library (first published 1967).

3. Bulgakov, M. (1989) The Master and Margarita. / Tr. by M. Ginsburg. London: Pan Books Ltd (first published 1967).

4. Bulgakov M. (1997) The Master and Margarita. / Tr. by R. Pevear and L. Volokhonsky, Penguin Books.

5. Gogol', N.V. (1985) Mertvye dushi. Moskva: Hudozhestvennaja literatura.

6. Gogol, N. (1931) Dead Souls. / Tr. by D.J. Hogarth. London: J.M. Dent \& Sons, England, (first published in 1915).

7. Gogol, N. (1987) Dead Souls. / Tr. by Ch. English. Moskva: Raduga Publishers.

8. Sayers, D. (2016) The Nine Tailors. London: Hodder \& Stoughton, (first published in 1934).

9. Sayers, D. (1998) Devjat' udarov za upokoj. / Perev. M. Vorsanovoj. Moskva: 'Armada'.

10. Sayers, D. (2008) Pocherk ubijcy (Devjat' portnyh). / Perev. A. Jashinoj. Moskva: Mir knigi. 


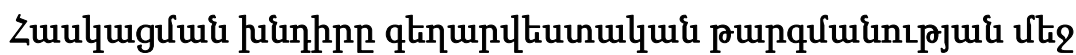

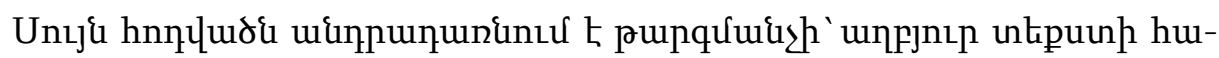

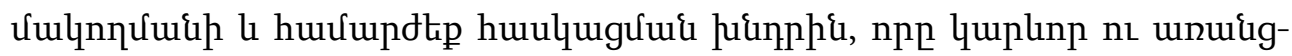

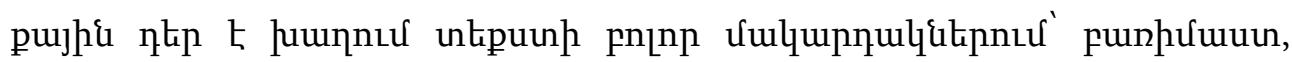

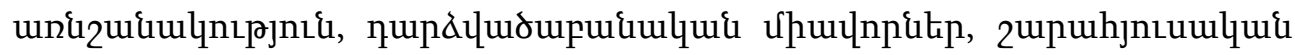

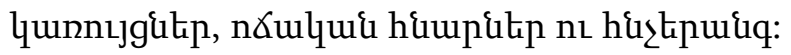

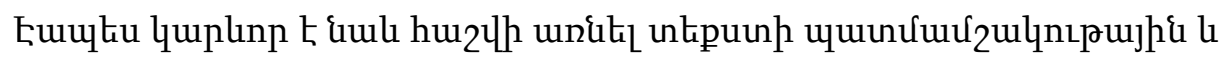

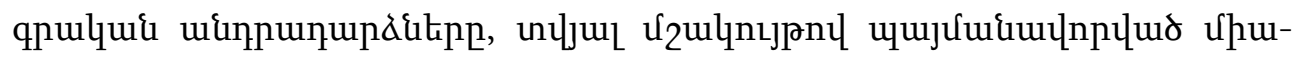

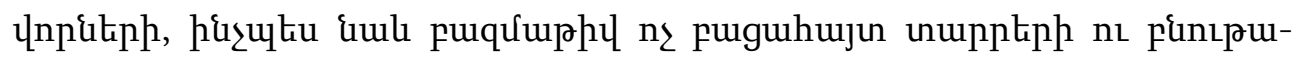

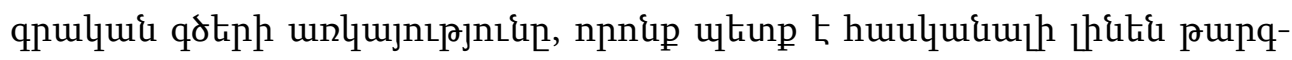

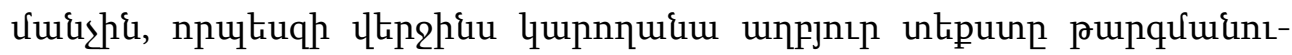

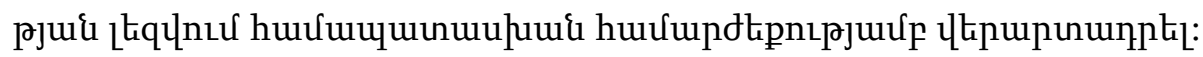

Received by Editorial Board 11.09.2019

Recommended for publication by Reviewers 23.10.2019

Accepted for Print 01.11.2019 